\title{
SURFACE PROPERTIES OF MDF COATED WITH CALCITE/CLAY AND EFFECTS OF FIRE RETARDANTS ON THESE PROPERTIES
}

\author{
Abdullah Istek ${ }^{1}$, Deniz Aydemir ${ }^{\wedge}$, Hudaverdi Eroglu ${ }^{1}$
}

\begin{abstract}
The coating of wood and wood panel surfaces basically serves for surface protection and its surface can be improved at various user areas. Different application methods are used for the coating of MDF surface. These are methods such as curtain coating, spraying, rolling, knife, etc. In this study, suitability of pigment coating method instead of the traditional surface coating methods used for coating MDF panels and the effects of fire retardants on surface properties of MDF coated by the best appropriate coating mixture was investigated. Calcite and clay were used as coating pigment and latex, urea formaldehyde, and melamine formaldehyde were used as adhesive. Coating/adhesive mixture obtained was applied to MDF panels with knives. Before the analysis, test samples were put to condition room and they were kept in there for 1 week. According to the results obtained, the best appropriate coating material was found as calcite. $22 \%$ concentrated melamine formaldehyde as adhesive and $0.25 \mathrm{~mm}$ as coating thickness was determined better than other combinations. Borax, boric acid and zinc borate as fire retardant were added to calcite /melamine formaldehyde with $22 \%$ mixture. So, the effects of fire retardant on surface characterization were determined. Surface properties of coated MDF panels tested were found lower than standard requirements except for abrasion resistance.
\end{abstract}

Keywords: Coated MDF, pigment coating, calcite, clay, surface properties, and fire retardants.

\section{INTRODUCTION}

Wood based panels may be exposed to many harmful factors such as fungus, insects, termites, and humidity, low and high temperatures at their areas of use. In order to reducing the damage caused by these factors, wood based panels are coated by using different materials and different coating applications according to using conditions. In this industry, two different coating materials are used in solid or liquid form. Panels to be laminated can be coated with polyester films, phenol kraft papers, PVC or PVA/Urea based decorated papers, papers impregnated with different resins, papers with ammoniumsulphamate, thin papers, foil papers, wooden veneers as solid coating materials and lacquer paint as liquid coating materials (Bozkurt and Göker 1986).

Performance of panel surface during coating process is evaluated by characteristics of wood species and manufacturing method (Cassens and Feist 1991, Richter et al. 1995). Basic requirement for durable coating performance on the surface of wood-based panels is a good adhesion between the panel surface and the coating material. Manufacturing parameters such as the mixture of wood particle, the using ratio of adhesives, surface treatment, storage and conditioning of the boards appeared to be closely linked with the surface properties and their performance during coating (Barbu et al. 2000). The differences in thickness of the coating film performance of particleboards during coating process may be due to a many reasons, e.g., the difference in the moisture content of the boards, hygroscopic effect of resins, differences in the curing conditions and homogenous application of the paint (Rolleri and Roffael 2010).

\footnotetext{
${ }^{1}$ Bartin University, Faculty of Forestry, Department of Forest Products Engineering, 74100, Bartin-Turkey. 
Coating process is widely used in paper industry as well. Coating process can provide extra smoothness, quality, strength, brightness, etc. to paper products (Eroğlu and Usta 2004).

This process can increase surface quality of panels and improve its surface and color properties (Nemli 2000). In coating process, which is a commonly used technique, coating material/ adhesive mixture is applied on paper. Basic materials of the mixture include coating material (clay, calcite, etc.) and adhesive. Nowadays, calcite and clay are commonly used in coating process. Calcite and clay are important coating materials which can provide extra strength and good surface quality to paper and paper products. Calcite and clay can also be used as filling materials. Generally, there are three stages followed in coating applications. The first stage is the preparation of the coating material, choosing the right adhesive for bonding the coating material and the last stage is the application of the mixture properly. All coating materials are added to water and all of them are mixed by blender until this mixture is homogenous. Clay, calcite, $\mathrm{TiO}_{2}$ are commonly used as coating materials on paper industry; and starch, casein or soy protein and synthetic resins are also used as bonding materials (Casey 1961).

Panel board manufacturers try to obtain a decorative surface with coating process on particleboard (PB) and medium density fiberboard (MDF). These panels are produced as homogenous and flat surface. The panels have excellent surfaces with application of coating materials. These coated panels are utilized in the construction of cabinets, furniture, paneling, kitchen worktops, laboratories, and other industrial product applications. The performance of the coated panels is dependent on the quality of wood based panel and the type of the coating material (Sparkes 1993, Hoag 1992). Niazi and Gertjojensen (1979) found that coating of panel surfaces improved the dimensional stability of wood based panels. Groah et al. (1984) and Grigoriou (1987) also stated that formaldehyde emission decreased due to coating of wood based panel surface with vinyl film and melamine impregnated paper. Nemli (2003) researched the effects of melamine-impregnated papers on the surface of particleboard and found that coated surface of particleboard improved the physical, mechanical properties and decreased the formaldehyde emission of particleboard. MDF panels have smother surface and more homogenous and tighter skin than other panels. These properties are advantageous in coating of surface (Romer 2002).

The calcite and clay are important coating materials since they increase strength and improve physical and surface properties. At the same time; borax, boric acid or zinc borate can be added to coating material/adhesive mixture as a fire retardant depending on materials or the area of use (Casey 1961). Chemicals used as fire retardants generally may decrease many properties of wood and wood panels. It was found that fire retardant with boron decreased mechanical properties and surface quality of wood panels (Baysal et al. 2006, Ustaomer 2008). Therefore, the objectives of this study were to evaluate surface characterization of medium density fiberboard (MDF) coated by calcite and clay, and to choose the suitable surface coating material type, mixture ratio (\%) and adhesives at areas of use. The effect of fire retardants on surface quality was also researched because studies done on this subject are not enough and this paper can give new information to this field.

\section{MATERIAL AND METHODS}

MDF panels and adhesives (Latex, melamine formaldehyde (MF) and urea formaldehyde (UF) used in this study were obtained from Kastamonu Integrated Forest Industry Inc. (Turkey).

Calcite and clay were provided as solid from Farma Lab Inc. dimensions and thickness of MDF panels used were selected as $250 \times 400 \times 12 \mathrm{~mm}$. The surfaces of all panels were sanded to obtain a smooth surface and a good bonding. Preparing conditions and using ratios of coating materials were given in table 1. 
Table 1. Preparing conditions and amount of coating material.

\begin{tabular}{cccc}
\hline Materials & Ratio (\%) & Materials & Ratio \\
\hline Calcite & 100 & Dry mass & $50-65$ \\
Clay & 100 & Viscosity & $50-500 \mathrm{cp}$. \\
Latex & $10,14,18,22$ & $\mathrm{pH}$ & $8-11$ \\
Urea Formaldehyde & $10,14,18,22$ & Sodium Hexane Meta Phosphate & 1 \\
Melamine Formaldehyde & $10,14,18,22$ & Zinc borate & $1,2,3$ \\
Brighter & 0.3 & Coating thickness $(\mathrm{mm})$ & $0.15-0.20-0.25$ \\
Borax & $1,2,3$ & Boric Acid & $1,2,3$ \\
\hline
\end{tabular}

Ratios of materials used were determined according to dry mass of calcite and clay. Materials used in this study were added to water and all of them were mixed by blender until it became homogenous. Coating material was applied with knife to the panels. Color of all panels is white and their surfaces are smooth. Figure 1 shows how to apply coating process.

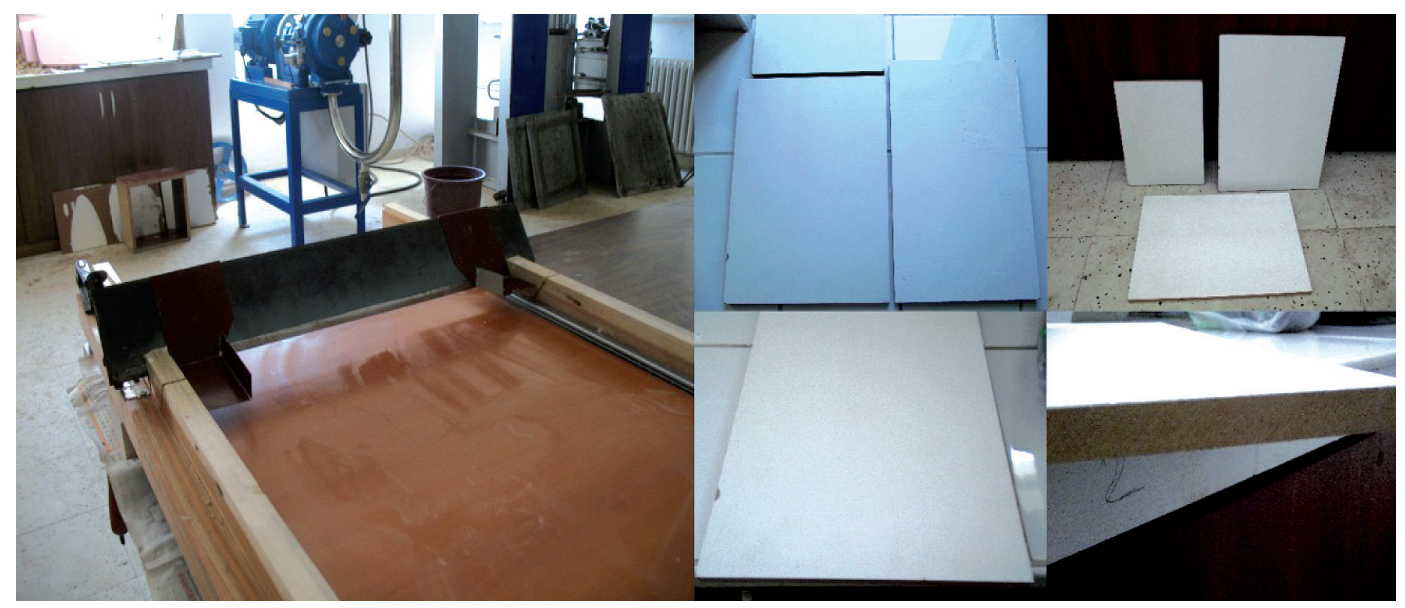

Figure 1. Coating Part and panels obtained after coating process.

Coating process was applied to the surface of all samples. Three replicates were done for each coating material/adhesive mixture. Coating material/adhesive mixture was applied on all samples with knife. Thicknesses of coating/adhesive mixture were $0.15,0.20$ and $0.25 \mathrm{~mm}$. After coating process, different properties of coated panels were determined. Tests investigated, tests performed and standards tracked were given in table 2. According to the results obtained, borax, boric acid and zinc borate as fire retardant were added to the best mixture. Ratio of fire retardants were 1, 2, and 3\%.

Table 2. Test done after coating process.

\begin{tabular}{cccc}
\hline Tests & Standards & Tests & Standards \\
\hline Surface roughness & ISO 8791/2 & Resistance to water steam & TS EN 14323 \\
Abrasion test & TS 1770 & Cracking Test & TS EN 14323 \\
Scratch test & TS EN 14323 & Resistance to stain & TS EN 14323 \\
\hline
\end{tabular}

Resistance to water steam, the resistance of the laminated particleboard to hot steam is measured by steam test. This test can be regarded as an endurance test to simulate the effect of the influence of steam. Resistance to stain is a test of the sensitivity of a surface to the effect of foreign substance. Evaluation table for stain and steam test was given here; 5 degree: No observable changes, 4 degree: little change in color and brightness, 3 degree: little change in color and/or brightness, 2 very large change in color and/or brightness, 1 degree: delaminating or/and blistering. 


\section{RESULTS AND DISCUSSION}

\section{Surface Characterization of MDF coated by mixture of calcite/clay}

The results were showed that adhesives used and coating materials have an important effect on surface properties. Effect of melamine formaldehyde on surface quality was determined to be higher as compared with other adhesives. It was also found that all surface properties (expect for abrasion test) were lower than the related standards. Abrasion values were determined to be higher when melamine formaldehyde was used as coating material compare with the other adhesives. It was also found that while the amount of melamine formaldehyde and coating thickness increased, the surface quality of panels promoted as well. The best surface quality of panels was obtained at $22 \%$ melamine formaldehyde and $0.25 \mathrm{~mm}$ coating thickness. It was found that when coating thickness was increased from $0.15 \mathrm{~mm}$ to $0.25 \mathrm{~mm}$, abrasion and scratch increased. At the same time, it was determined that calcite and clay have not important effect on surface quality. All data obtained were given table 3-12.

Table 3. Surface characterization of MDF coated with Clay-Latex $(0.20 \mathrm{~mm})$.

\begin{tabular}{ccccc}
\hline \multirow{2}{*}{ Surface Properties } & \multicolumn{4}{c}{ Latex Ratio (\%) } \\
\cline { 2 - 5 } & 10 & 14 & 18 & 22 \\
\hline Abrasion test $(\mathrm{rpm})$ & 50 & 75 & 120 & 140 \\
Scratch test (N) & 0.4 & 0.7 & 0.8 & 1 \\
Resistance to water steam (degree) & 1 & 1 & 1 & 1 \\
Resistance to cracking $\left(\mathrm{mm}^{2}\right)$ & $>2$ & $>2$ & $>2$ & $>2$ \\
Resistance to stain $($ degree) & 1 & 1 & 1 & 1 \\
Surface roughness (ml/min) & 1375 & 1295 & 1245 & 1225 \\
\hline
\end{tabular}

Table 4. Surface characterization of MDF coated with Calcite-Latex $(0.20 \mathrm{~mm})$.

\begin{tabular}{ccccc}
\hline \multirow{2}{*}{ Surface Properties } & \multicolumn{4}{c}{ Latex Ratio (\%) } \\
\cline { 2 - 5 } & 10 & 14 & 18 & 22 \\
\hline Abrasion test (rpm) & 100 & 100 & 110 & 120 \\
Scratch test (N) & 0,5 & 0,7 & 0,8 & 1 \\
Resistance to water steam (degree) & 1 & 1 & 1 & 1 \\
Resistance to cracking $\left(\mathrm{mm}^{2}\right)$ & $>2$ & $>2$ & $>2$ & $>2$ \\
Resistance to stain (degree) & 1 & 1 & 1 & 1 \\
Surface roughness (ml/min) & 1325 & 1295 & 1280 & 1255 \\
\hline
\end{tabular}

Table 5. Surface characterization of MDF coated with Clay-UF $(0.20 \mathrm{~mm})$.

\begin{tabular}{ccccc}
\hline \multirow{2}{*}{ Surface Properties } & \multicolumn{4}{c}{ Urea Formaldehyde Ratio (\%) } \\
\cline { 2 - 5 } & 10 & 14 & 18 & 22 \\
\hline Abrasion test (rpm) & 50 & 75 & 100 & 120 \\
Scratch test (N) & 0,5 & 0,6 & 0,8 & 0,8 \\
Resistance to water steam (degree) & 1 & 1 & 1 & 1 \\
Resistance to cracking (degree) & $>2$ & $>2$ & $>2$ & $>2$ \\
Resistance to stain (mm $\left.\mathrm{mm}^{2}\right)$ & 1 & 1 & 1 & 1 \\
Surface roughness $\left(\mathrm{ml} / \mathrm{min}^{2}\right)$ & 1325 & 1315 & 1290 & 1295 \\
\hline
\end{tabular}

Table 6. Surface characterization of MDF coated with Calcite-UF $(0.20 \mathrm{~mm})$.

\begin{tabular}{ccccc}
\hline Surface Properties & \multicolumn{4}{c}{ Urea Formaldehyde Ratio (\%) } \\
\cline { 2 - 5 } & 10 & 14 & 18 & 22 \\
\hline Abrasion test (rpm) & 50 & 75 & 100 & 110 \\
Scratch test (N) & 0,4 & 0,7 & 0,8 & 0,8 \\
Resistance to water steam (degree) & 1 & 1 & 1 & 1 \\
Resistance to cracking (mm $\left.{ }^{2}\right)$ & $>2$ & $>2$ & $>2$ & $>2$ \\
Resistance to stain (Degree) & 1 & 1 & 1 & 1 \\
Surface roughness (ml/min) & 1330 & 1315 & 1310 & 1285 \\
\hline
\end{tabular}


Table 7. Surface characterization of MDF coated with Clay-MF $(0.20 \mathrm{~mm})$.

\begin{tabular}{ccccc}
\hline \multirow{2}{*}{ Surface Properties } & \multicolumn{4}{c}{ Melamine Formaldehyde Ratio (\%) } \\
\cline { 2 - 5 } & 10 & 14 & 18 & 22 \\
\hline Abrasion test $(\mathrm{rpm})$ & 75 & 75 & 110 & 175 \\
Scratch test $(\mathrm{N})$ & 0.6 & 0.7 & 0.9 & 1.5 \\
Resistance to water steam (degree) & 1 & 1 & 1 & 1 \\
Resistance to cracking $\left(\mathrm{mm}^{2}\right)$ & $>2$ & $>2$ & $>2$ & $>2$ \\
Resistance to stain $($ degree) & 1 & 1 & 1 & 1 \\
Surface roughness (ml/min) & 1315 & 1290 & 1295 & 1280 \\
\hline
\end{tabular}

Table 8. Surface characterization of MDF coated with Calcite-MF $(0.20 \mathrm{~mm})$.

\begin{tabular}{ccccc}
\hline \multirow{2}{*}{ Surface Properties } & \multicolumn{4}{c}{ Melamine Formaldehyde Ratio (\%) } \\
\cline { 2 - 5 } & 10 & 14 & 18 & 22 \\
\hline Abrasion test (rpm) & 50 & 75 & 120 & 175 \\
Scratch test (N) & 0.4 & 0.8 & 0.9 & 1.4 \\
Resistance to water steam (degree) & 1 & 1 & 1 & 1 \\
Resistance to cracking $\left(\mathrm{mm}^{2}\right)$ & $>2$ & $>2$ & $>2$ & $>2$ \\
Resistance to stain $($ degree) & 1 & 1 & 1 & 1 \\
Surface roughness (ml/min) & 1395 & 1345 & 1305 & 1310 \\
\hline
\end{tabular}

Table 9. Surface characterization of MDF coated with Clay-MF $(0.15 \mathrm{~mm})$.

\begin{tabular}{ccccc}
\hline \multirow{2}{*}{ Surface Properties } & \multicolumn{4}{c}{ Melamine Formaldehyde Ratio (\%) } \\
\cline { 2 - 5 } & 10 & 14 & 18 & 22 \\
\hline Abrasion test (rpm) & 50 & 75 & 110 & 150 \\
Scratch test (N) & 0.4 & 0.5 & 0.8 & 1 \\
Resistance to water steam (degree) & 1 & 1 & 1 & 1 \\
Resistance to cracking $\left(\mathrm{mm}^{2}\right)$ & $>2$ & $>2$ & $>2$ & $>2$ \\
Resistance to stain (degree) & 1 & 1 & 1 & 1 \\
Surface roughness (ml/min) & 1315 & 1285 & 1290 & 1265 \\
\hline
\end{tabular}

Table 10. Surface characterization of MDF coated with Clay-MF $(0.25 \mathrm{~mm})$.

\begin{tabular}{ccccc}
\hline \multirow{2}{*}{ Surface Properties } & \multicolumn{4}{c}{ Melamine Formaldehyde Ratio (\%) } \\
\cline { 2 - 5 } & 10 & 14 & 18 & 22 \\
\hline Abrasion test (rpm) & 75 & 120 & 150 & 200 \\
Scratch test (N) & 1 & 1.2 & 1.4 & 1.5 \\
Resistance to water steam (degree) & 1 & 1 & 1 & 1 \\
Resistance to cracking $\left(\mathrm{mm}^{2}\right)$ & $>2$ & $>2$ & $>2$ & $>2$ \\
Resistance to stain (degree) & 1 & 1 & 1 & 1 \\
Surface roughness (ml/min) & 1365 & 1325 & 1310 & 1265 \\
\hline
\end{tabular}

Table 11. Surface characterization of MDF coated with Calcite-MF $(0.15 \mathrm{~mm})$.

\begin{tabular}{ccccc}
\hline \multirow{2}{*}{ Surface Properties } & \multicolumn{4}{c}{ Melamine Formaldehyde Ratio (\%) } \\
\cline { 2 - 5 } & 10 & 14 & 18 & 22 \\
\hline Abrasion test (rpm) & 50 & 50 & 100 & 150 \\
Scratch test (Newton) & 0.4 & 0.5 & 0.8 & 1 \\
Resistance to water steam (degree) & 1 & 1 & 1 & 1 \\
Resistance to cracking $\left(\mathrm{mm}^{2}\right)$ & $>2$ & $>2$ & $>2$ & $>2$ \\
Resistance to stain (degree) & 1 & 1 & 1 & 1 \\
Surface roughness (ml/min) & 1375 & 1315 & 1285 & 1295 \\
\hline
\end{tabular}


Table 12. Surface characterization of MDF coated with Calcite-MF $(0.25 \mathrm{~mm})$.

\begin{tabular}{ccccc}
\hline Surface Properties & \multicolumn{4}{c}{ Melamine Formaldehyde Ratio (\%) } \\
\cline { 2 - 5 } & 10 & 14 & 18 & 22 \\
\hline Abrasion test (rpm) & 75 & 150 & 190 & 220 \\
Scratch test (Newton) & 1 & 1.3 & 1.4 & 1.6 \\
Resistance to water steam (degree) & 1 & 1 & 1 & $>2$ \\
Resistance to cracking $\left(\mathrm{mm}^{2}\right)$ & $>2$ & $>2$ & $>2$ & 1 \\
Resistance to stain (degree) & 1 & 1 & 1 & 1370 \\
Surface roughness (ml/min) & 1385 & 1350 & 1310 & \\
\hline
\end{tabular}

Surface roughness of coated MDF samples was determined with Bendtsen device according to ISO 8791/2 standard. Surface roughness was measured as milliliters/sec. and this device uses air for measuring surface roughness. The device sends air to sample and surface roughness is found as flowing amount. If the flowing amount is high, the surface of panel is not smooth. If the flowing amount is low, the panel has a smooth surface. As seen in table 3-12, Adhesive type, using ratio and coating materials were determined to have an important effect on surface roughness. Datum obtained showed that there is a linear relationship between abrasion and resistance to scratch. According to results, the best appropriate adhesive, coating material and coating thickness were found as melamine formaldehyde (22\%), calcite and $0.25 \mathrm{~mm}$, respectively. Ozdemir et al. (2009) researched the effect of humidity on surface roughness. The results appear that surface quality of the panels adversely influenced from increasing relative humidity. When relative humidity served as a variable, the surface quality of coated MDF panels revealed that values of such samples increased as compared to those of samples at initial condition (Hiziroglu et al. 2008).

Istek et al. (2010) evaluated the effect of decor paper and resin type on surface quality properties of particleboards coated with decor papers impregnated by using different resins. The results revealed that specimens coated with melamine formaldehyde-impregnated papers showed better performance than those coated with urea formaldehyde and urea + melamine formaldehyde-impregnated papers. It was found that resin types and paper pattern affected surface properties, such as impact, scratch, and abrasion, resistance to staining and cigarette burn. However, it did not change the cracking and steaming properties of the coated samples.

\section{The Effects of Fire Retardants on Surface Characterization of coated MDF Samples:}

Coating formulations were prepared with MF-resin, calcite, clay and calcite-clay for different mixing ratios $(100 \% / 0 \%, 30 \% / 70 \%, 50 \% / 50 \%, 70 \% / 30 \%$ and $0 \% / 100 \%)$ and were applied to panel surfaces at $0.25 \mathrm{~mm}$ thickness (Table 13 ).

Table 13. Surface characterization of MDF coated by clay/calcite mixture

\begin{tabular}{cccccc}
\hline \multirow{2}{*}{ Surface Properties } & \multicolumn{5}{c}{ Clay\%/Calcite\%(Coating Mixture) } \\
\cline { 2 - 6 } & $100 / 0$ & $30 / 70$ & $50 / 50$ & $70 / 30$ & $0 / 100$ \\
\hline Abrasion test (rpm) & 218 & 175 & 170 & 170 & 220 \\
Scratch test (N) & 1.6 & 1.5 & 1.5 & 1.6 & 1.6 \\
Resistance to water steam (degree) & 2 & 1 & 1 & 1 & 2 \\
Resistance to cracking $\left(\mathrm{mm}^{2}\right)$ & $>2$ & $>2$ & $>2$ & $>2$ & $>2$ \\
Resistance to stain (degree) & 1 & 1 & 1 & 1 & 1 \\
Surface roughness (ml/min) & 1366 & 1315 & 1370 & 1345 & 1370 \\
\hline
\end{tabular}

According to the related standards, 4 degree and 1 degree show the best properties and the worst properties, respectively.

According to table 13, it was found that surface properties of MDF coated by $70 \%$ clay-30\% clay, $50 \%$ clay- $50 \%$ calcite mixture, and $30 \%$ clay- $70 \%$ calcite at $0.25 \mathrm{~mm}$ thickness were lower than 
$100 \%$ calcite and $100 \%$ clay mixtures. Resistance to water steam was found to change between 1 and 2 degree, but resistance to stain was not changed to all formulations. It is 1 degree, which are the lowest values for all formulations. Consequently, resistances to stain and water steam were found to be low. Scratch was determined to be $\geq 1.5 \mathrm{~N}$ for all coated panels. Surface roughness for all samples ranged from $1315 \mathrm{ml} / \mathrm{min}$ to $1370 \mathrm{ml} / \mathrm{min}$. The best abrasion strength was found to $100 \%$ calcite. As a result, using clay-calcite mixture as coating materials didn't cause an important difference on surface properties of all samples. Using only calcite or only clay was seen to be better than using calcite-clay mixture. Therefore, $100 \%$ calcite was used to determine the effects of fire retardants on surface characterization of MDF. Borax, boric acid and zinc borate were added to mixture as $1 \%, 2 \%$ and $3 \%$ ratios of fire retardants. Melamine formaldehyde was also added to have to bonding between coating formulation and panel surfaces. The mixture obtained was applied to panels at $0.25 \mathrm{~mm}$ thickness. The effects of added fire retardants such as borax, boric acid and zinc borate on surface properties were given table 14,15 and 16.

Table 14. Surface characterization of MDF coated by Coating Material/Borax.

\begin{tabular}{ccccc}
\hline \multirow{2}{*}{ Surface Properties } & \multirow{2}{*}{ Control } & \multicolumn{3}{c}{ Borax Ratio (\%) } \\
\cline { 3 - 5 } & & 1 & 2 & 3 \\
\hline Abrasion test (rpm) & 220 & 215 & 175 & 170 \\
Scratch test (N) & 1.6 & 1.6 & 1.5 & 1.5 \\
Resistance to water steam (degree) & 2 & 2 & 1 & 1 \\
Resistance to cracking (mm $\left.{ }^{2}\right)$ & $>2$ & $>2$ & $>2$ & $>2$ \\
Resistance to stain (degree) & 1 & 1 & 1 & 1 \\
Surface roughness (ml/min) & 1370 & 1365 & 1315 & 1370 \\
\hline
\end{tabular}

According to table 14, adding of borax did not change cracking and stain as compare with control samples. However; abrasion, scratch were decreased and surface roughness decreased to $1 \%$ and $2 \%$. But; it did not change to $3 \%$ adding of borax.

Table 15. Surface characterization of MDF coated by Coating Material/Boric Acid.

\begin{tabular}{ccccc}
\hline Surface Properties & \multirow{2}{*}{ Control } & \multicolumn{3}{c}{ Boric Acid Ratio (\%) } \\
\cline { 3 - 5 } & & 1 & 2 & 3 \\
\hline Abrasion test (rpm) & 220 & 150 & 175 & 175 \\
Scratch test (N) & 1.6 & 1.8 & 2 & 1.8 \\
Resistance to water steam (degree) & 2 & 2 & 1 & 1 \\
Resistance to cracking (mm $\left.{ }^{2}\right)$ & $>2$ & $>2$ & $>2$ & $>2$ \\
Resistance to stain (degree) & 1 & 2 & 2 & 1 \\
Surface roughness (ml/min) & 1370 & 1395 & 1436 & 1474 \\
\hline
\end{tabular}

As seen as table $15,1 \%$ boric acid decreased abrasion but, it increased surface roughness. According to control samples, adding of $2 \%$ boric acid had a lightly increasing effect on abrasion and scratch. Boric acids for all adding ratios $(1 \%, 2 \%$, and $3 \%)$ also have an increasing effect on surface roughness. Increasing of surface roughness value indicates deterioration of the surface. Adding of boric acid did not cause an important effect on resistance to water steam, cracking and stain.

Table 16. Surface characterization of MDF coated by Coating Material/Zinc Borate.

\begin{tabular}{ccccc}
\hline Surface Properties & \multirow{3}{*}{ Control } & \multicolumn{3}{c}{ Zinc Borate Ratio (\%) } \\
\cline { 3 - 5 } & & 1 & 2 & 3 \\
\hline Abrasion test (rpm) & 220 & 150 & 170 & 175 \\
Scratch test (N) & 1.6 & 1.7 & 1.8 & 1.8 \\
Resistance to water steam (degree) & 2 & 2 & 1 & 1 \\
Resistance to cracking $\left(\mathrm{mm}^{2}\right)$ & $>2$ & $>2$ & $>2$ & $>2$ \\
Resistance to stain (degree) & 1 & 1 & 2 & 2 \\
Surface roughness (ml/min) & 1370 & 1335 & 1371 & 1394 \\
\hline
\end{tabular}


In table 16, abrasion was found to be lower as comparison with control panels. Zinc borate was affected all surface roughness except for resistance to cracking. All ratios of zinc borate improved scratch and resistance to stain. However; it decreased abrasion, resistance to water steam and surface roughness according to control samples. As a result, surface roughness had generally a change for worse by adding of fire retardants. Whereas, zinc borate and boric acid were found to increased scratch.

Ayrilmis et al. (2006) investigated the effect of various fire retardants such as borax, boric acid, monoammonium phosphate and diammoniumphosphate on the surface roughness of plywood. Significant difference was determined between surface roughness parameters ( $R a$; Roughness Average, Rz; Average Maximum Height of the Profile, Rmax; Maximum Roughness Depth) for four treatments and two retentions of fire retardants. Samples treated with 3\%concentration of borax had the smoothest surface with 11:09 $\mathrm{mm}$ Ra while the roughest surface was found in samples treated with $6 \%$ boric acid having Ra value of 12:44 mm. Results revealed that the surface quality of the panel decreased as the ratio of fire retardants increased. Previous work on FRT blockboard plywood found that increased chemical concentrations gave higher retention values which in turn resulted in better fire resistance characteristics of the samples (Laufenberg et al. 2006). However, this study indicates that surface roughness of the panels can be adversely influenced by increased concentrations of fire retardants.

Rolleri and Roffael (2010) studied on coating and surface properties of particleboards. The results obtained shows that, in general, higher values of roughness of uncoated particleboards lead to thinner coating films on the surface. Particleboards made with fresh and recycled particles showed higher values of average roughness $(\mathrm{Ra})$ and higher adherence strength to the coating compared to particleboards with cork particles, which had a relatively smooth surface. Not only the roughness of the surface but also interaction between the primer and surface seems to be a very important factor determining the strength of adhesion between primer and the surface.

\section{CONCLUSION}

Coating of panel surfaces is an important factor for end-use application of wood based panels. In this study, properties of panels coated by Latex, MF and UF and effects of fire retardants on these properties were investigated. According to the results, all coating materials used caused an important difference on panel surface properties and the best results for all formulation used was obtained for melamine formaldehyde as adhesive and $0.25 \mathrm{~mm}$ as coating thickness. Calcite (100\%), clay (100\%) or mixture of clay/calcite (30\%-70\%, 50\%-50\% and 70\%-30\%) did not cause a significant difference on surface quality. Surface quality of panels coated with only $100 \%$ clay or only $100 \%$ calcite was found to be similar when compared to panels coated by mixture of clay/calcite. But calcite was found to be better than the other formulations. Therefore; calcite was used for determining of effects of fire retardants on surface properties. Borax, boric acid, and zinc borate were added to $100 \%$ calcite. The lowest value of abrasion was determined for $1 \%$ zinc borate and boric acid. Nevertheless, adding of borax $(1 \%)$ was decreased more than the other ratios of fire retardants as comparison with control samples. As seen as scratch properties, it increased by adding of zinc borate and boric acid. Surface roughness was determined to affect negatively for all formulations except for $2 \%$ and $3 \%$ adding of boric acid. As results, the adding of fire retardants were not improved the properties of the panel surfaces.

\section{ACKNOWLEDGEMENT}

This study was funded by the project numbered with 2008-Ç0197 by National Boron Research Institute (BOREN). The authors would like to thank to Dr. S. Koray Gulsoy for helping some experimental tests and The Institute of BORON (BOREN) for supporting the found. 


\section{REFERENCES}

Ayrilmis, A.; Korkut, S.; Tanritanir, E.; Winandy, J.E.; Hiziroglu, S. 2006. Effect of various fire retardants on surface roughness of plywood. Building and Environment 41(7): 887-892.

Barbu, M.; Resch, H.; Pruckner, M. 2000. The wettability of medium density fibreboards. Proceedings of the 4th European Panel Products Symposium, Llandudno, Wales, UK. 11th - 13th October 2000. 14-21 pp.

Baysal, E.; Şimşek, H.; Toker, M.; Çolak, M.; Yiğitbaşı, N.O. 2006. Borlu Bileşiklerle Muamele Edilen Ağaç Malzemede Higroskopisite Seviyelerinin Belirlenmesi. National Boron Sympossium Book, Ankara, Turkey, 51-54 pp.

Bozkurt, A.Y.; Göker, Y. 1986. Tabakalı Ağaç Malzeme Teknolojisi. Istanbul University Press, Istanbul, $287 \mathrm{pp}$.

Casey, J.P. 1961. Pulp and Paper. Volume II Papermaking. Interscience Publishers, NewYork. USA, 1000 pp.

Cassens, D.L.; Feist, W.C. 1991. Exterior wood in the South. Selection, application and finishes. GTR-69. USDA Forest Serv., Forest Prod. Lab., Madison, Wis. USA. 56 pp.

Eroğlu, H.; Usta, M. 2004. Kâğıt ve Karton Üretim Teknolojisi. Esen Ofset Press, Trabzon. 395 pp

Grigoriou, A. 1987. Formaldehyde emission from the edges and faces of various wood based materials. Holz als Roh und Werkstoff 45(2): 63-7.

Groah, W.J.; Gramp, G.D.; Trant, M. 1984. Effect of decorative vinyl overlay on formaldehyde emission. Forest Product Journal 34(4): 27-29.

Hiziroglu, S., Jarusombuti, S., Bauchongkol, P., Fueangvivat, V. 2008. Overlaying properties of fiberboard from bamboo and rice straw. Industrial Crops and Products 28: 107-111.

Hoag, M. 1992. Surface testing of particleboard and medium density fiberboard for laminating applications. Tappi Journal 75: 116-121.

Istek, A.; Aydemir, D.; Aksu, S. 2010. The effect of decor paper and resin type on the physical, mechanical, and surface quality properties of particleboards coated with impregnated decor papers. BioResources 5(2): 1074-1083.

Laufenberg, T.; Ayrilmis, N.; White, R. 2006. Fire and bending properties of blockboard with fire retardant treated veneers. Holz als Roh- und Werkstoff 64 (2): 137-143.

Nemli, G. 2000. Yüzey Kaplama Malzemelerive Uygulama Parametrelerinin Yongalevha Teknik Özellikleri Üzerine Etkileri. Dissertation Thesis, Blacksea Technical University, Trabzon, Turkey.

Nemli, G. 2003. Sentetik Laminat Endüstrisi. Faculty of Forestry Press, Trabzon. Turkey.

Niazi, A.K.; Gertjojensen, R.O. 1979. Linear dimensional stability of aspen veneered particleboard. Forest Product Journal 29(5): 28-29. 
Ozdemir, T.; Hiziroglu, S.; Malkocoglu, A. 2009. Influence of relative humidity on surface quality and adhesion strength of coated medium density fiberboard (MDF) panels. Materials and Design 30 (10): 2543-2546.

Richter, K.; Feist, W.C.; Knaebe, M.T. 1995. The effect of surface roughness on the performance of finish. Part 1. Roughness characterization and stain performance. Forest Products Journal 45 (7-8): 91-96.

Rolleri, A.; Roffael E. 2010. Influence of the Surface Roughness of Particleboards and Their Performance towards Coating. Maderas Ciencia y Tecnologia 12(2): 143-148.

Romer, J. 2002. Coating MDF Furniture with Powder: The First Industrial Series Production. Powder Coating Europe Congress, Nurenberg- Janvier, Germany.

Sparkes, T. 1993. Substrate selection for end user applications. European Plastic Laminates Forum, Koln, Germany. 27-31 pp.

Ustaomer, D. 2008. Odun ve Odun Esaslı Levhalar için Yanma Özellikleri, Yanmayı Geciktirici Kimyasal Maddeler ve Bu Maddelerin Etkileri. Düzce University Faculty of Forestry, VI. The National Student Council of Forestry Faculty, 418-425 pp. 